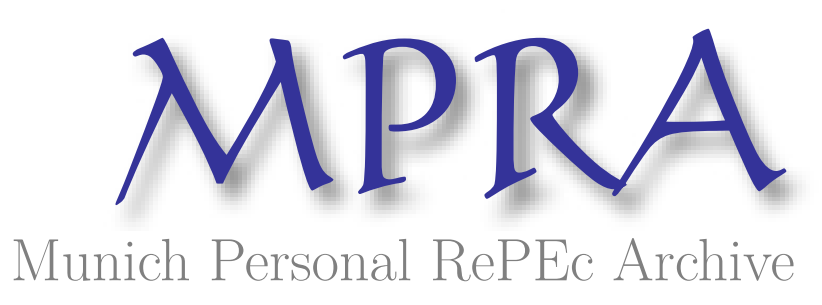

\title{
Determinants of Post-congressional Lobbying Employment
}

Kim, Jin-Hyuk

5 May 2012

Online at https://mpra.ub.uni-muenchen.de/82375/

MPRA Paper No. 82375, posted 08 Nov 2017 22:33 UTC 


\section{Introduction}

The revolving door from Capitol Hill to the lucrative lobbying industry has received much criticism from the press and concerned citizens, such as the Occupy Wall Street protesters. Public Citizen, a watchdog organization, reported that between 1998 and 2004, 43 percent of the 198 members who left Congress and were eligible to lobby have become registered lobbyists and concluded that urgent reforms such as extending the cooling-off period are needed to ensure government accountability (Public Citizen 2005). In fact, members of Congress such as Rep. Bill Posey (R-FL) and Sen. Michael Bennet (D-CO) introduced bills in 2009 (Posey) and 2010 (Bennet) that would either permanently or for five years ban all lobbying by ex-members of Congress.

It is well-known that the financial appeal of lobbying is hard to resist. The First Street Research Group analyzed lobbying disclosure data in 2011 and found that the average amount received by ex-members of Congress per client topped $\$ 178,000$ with the ex-members representing an average of 31 clients. ${ }^{1}$ This certainly looks like politicians are being bought by the special interests groups that spend the most to hire them. Yet, surprisingly little work has been done in political science or economics that contributes to this issue of growing concern for public policy. This paper is motivated by the need to bridge this gap and aims to examine the determinants of post-congressional lobbying employment.

Specifically, I relate measures of legislators' characteristics, legislative behavior, and changes in behavior to their post-congressional lobbying employment. Departing from existing studies, I compare two groups of legislators, that is, those who voluntarily retired from

\footnotetext{
${ }^{1}$ See $<$ http://firststreetresearch.cqpress.com/first-street-30/>.
} 
Congress and those who were voted out of office. The reason for taking this selection-based approach is that a pooled-sample regression assumes a common underlying mechanism even though these two groups of legislators might be treated differently in the job market for lobbyists. For instance, the employers of lobbyists likely seek different qualifications than voters and would view the two groups differently.

In the existing literature on congressional careers, the main focus has been on the member's retirement decision. However, relatively little attention has been paid to the study of the revolving doors between Congress and the lobbying industry. This paper adds to previous studies by examining the determinants of the member's retirement decision in the first stage, but the main contribution of this paper comes from the second stage of estimation where determinants of lobbying employment are examined taking into account the propensity to retire voluntarily from Congress. I test multiple hypotheses, for instance, whether lobbying employment is correlated with changes in the legislators' voting behavior in their last term in office.

Using a relatively rich dataset, a number of findings become obvious. For instance, voluntarily retiring from Congress is unlikely to be a determining factor for one's decision to pursue a lobbying career. Instead, I argue that these two groups (those who voluntarily retired and those not re-elected) are different in an unmeasured way that would affect both the probability of retiring and finding a lobbying career at the same time. That is, the selection bias from voluntary retirement is likely to be present, and in fact I find that the direction of bias works in favor of those who voluntarily retire from Congress. That is, their probability of landing a lobbying job is higher indicating that the revolving doors are more open to ex-members who did not lose an election. 
Further, I find that the determinants of lobbying employment exhibit systematic differences between the two groups in terms of estimated coefficients. The main empirical findings are that the legislators who become lobbyists after losing an election tend to have more conservative voting records relative to the median voter in Congress, and they also have served on a major committee(s) compared to those who do not become lobbyists. However, these effects are largely absent for those who voluntarily retire from Congress. For this group, the length of congressional tenure and a decrease in conservative voting score as well as a slowdown of legislative activities such as bill sponsorship in their last term are important predictors of lobbying.

These findings suggest that there might be two kinds of revolving doors between Congress and the lobbying industry. That is, those who are electorally weak (did not get re-elected) need to serve on an important committee(s) and be relatively conservative to be attractive to the mostly conservative, corporate lobbying clients. On the other hand, those who voluntarily retire have less commitment to their constituency, so there seems to be some degree of shirking in terms of deviations from past voting records and the number of bills that they introduced during their last term. Because members can time their retirement, their congressional tenure rather than specific knowledge gained from serving on committees seems to matter the most.

I also compare and contrast two competing (or complementary) hypotheses regarding the ideology of former legislators who become lobbyists. One is that lobbying firms tend to hire ideologically moderate members of Congress who can influence the median voter. The other is that the demand for conservative lobbyists outweighs that for liberal lobbyists. It turns out that the data fit the latter hypothesis better than the former. Further, in contrast to 
what the first hypothesis predicts, there is evidence that the retiring members who become lobbyists tend to deviate from their past voting records in their last term away from the congressional median. That is, rather than moderating, they tend to take ideologically more extreme voting positions.

The outline for this paper is as follows. Section 2 discusses the relevant literature. Section 3 briefly reviews the ethics rule in Congress. Section 4 lays out the hypotheses and empirical methods. Section 5 describes the dataset, and Section 6 contains the main results. Section 7 presents concluding remarks.

\section{Related Literature}

The literature on congressional careers has a long history in political science, where a number of authors have focused on the determinants of the member's decision to run for re-election or retire from Congress (e.g., Kiewiet and Zeng 1993; Groseclose and Krehbiel 1994; Hall and van Houweling 1995). Economists have recently contributed to this literature by investigating the post-congressional careers of those who left Congress. For instance, Diermeier et al. (2005) estimated a dynamic structural model of post-congressional wages of former members of Congress and showed that congressional experience increases the member's post-congress wage in the private sector. This paper contributes to this literature by investigating what determines, specifically, the lobbying employment of former Representatives, and how it differs based on whether they lost their re-election bids. ${ }^{2}$

\footnotetext{
${ }^{2}$ There are a couple of recent studies that look at the value of political connections to incumbent politicians from the standpoint of lobbyists (see, e.g., Blanes i Vidal et al. 2010; and Bertrand et al. 2011). The difference is that this paper focuses on the Congress-to-lobbying revolving door, whereas these two papers do not distinguish between the professional lobbyists and congressmen-turned-lobbyists. For the industry-
} 
More closely related is the political science literature on the U.S. Congress. Earlier works in this literature are based on survey interviews. For instance, Milbrath (1963), based on a 1956 sample of 114 registered lobbyists, found that a working knowledge of the subject matter was the most important factor looked for in recruiting lobbyists. ${ }^{3}$ Similarly, Salisbury et al. (1989), based on a 1983 sample of 776 Washington lobbyists, found that government experience was valuable in terms both of substantive knowledge gained of process and familiarity with policy issues, rather than through contacts made from government experience. This is consistent with the findings in this paper in that committee assignments are important but cosponsorship networks are not. The novel part is that this relationship holds only for those who were voted out and not for those who chose to retire.

Because these studies are based on a survey of current lobbyists, they do not include the career choices of all eligible former legislators. That is, the surveys typically do not include former members who did not become lobbyists. Hence, it is difficult to draw implications from these studies on who is more likely to become a lobbyist and what legislative characteristics are correlated with post-congressional lobbying employment. Herrick and Nixon (1996) is the first empirical study to trace the members' post-congressional careers. Herrick and Nixon surveyed a subset of House members who retired between 1971 and 1992 and found that, among other factors, age can limit the opportunities for post-congressional employment, and while voted-out members tend to remain politically active those who retired voluntarily are less likely to work in the political arena. ${ }^{4}$

to-Cabinet revolving door, see also Gely and Zardkoohi (2001).

${ }^{3}$ Zeigler and Baer (1968) performed another study based on a 1966 survey of legislators and lobbyists in four U.S. states. Their primary focus was on the examination of the backgrounds of legislators and lobbyists, where they found that legislators and lobbyists share important backgrounds such as income, education, and occupation.

${ }^{4}$ Herrick and Nixon's finding that political employees were more likely to have been forced out of office does 
However, although Herrick and Nixon (1996) argued that members behave in such a way as to increase their marketability after they leave Congress, they relied on more direct measures of the politicians' interests and did not include variables such as voting records. Further, their classification of political employees includes both lobbyists and other government employees, thus the implications for Congress-to-lobbying revolving doors cannot be clearly drawn. Using a partial list of samples collected by Borders and Dockery (1995), Leal (2002) examined the former members' decisions on whether to live and/or become lobbyists in Washington after leaving Congress. Leal found that longer-serving members were more likely to work as lobbyists, whereas age and ideological distance from constituent preferences were negatively associated with lobbying employment. ${ }^{5}$

This paper is closest to the paper by Butler and Sovey (2010). Following the former members of the U.S. House of the 104th-109th Congresses, Butler and Sovey showed that leadership positions, committee assignments, and ideological moderation were important factors for the members' post-congressional lobbying employment. In particular, they addressed the endogeneity of a legislator's ideological location by using the ideology of the legislator's district as an instrumental variable. The empirical methodology used in this paper as well as the main hypothesis regarding how a legislator's ideology correlates with lobbying employment is substantially different from theirs. For instance, this paper estimates a sample selection model using term-limit pledges as an instrument for retirement decisions

not hold in this paper. One possible reason is that their sample selection could be biased, which they mention in their paper as well. That is, Herrick and Nixon relied on addresses in the directory of the Association of Former Members of Congress, which about 60 percent of former members belong. Importantly, members who opted to retire were much more likely to join the association than members who lost re-election bids or sought higher office.

${ }^{5}$ In this paper, the effect of tenure is positive only for the retiring group and not for the voted-out group. As Herrick and Nixon pointed out, Borders and Dockery's sample is not a random sample; it is based on anecdotes and case studies, which also suffer from selection or survivorship bias. 
and focuses on ideological conservatism not moderation as the main driver.

Finally, there is a strand of the literature that examines the last-term behavior of revolving-door regulators. This literature found largely mixed results. For instance, using the voting records of the Federal Communications Commission Commissioners, Gormley (1979) showed that the Commissioners who worked for broadcasting companies tended to vote in support of the broadcasting industry, but the effect was small once other measures were put into place to control for their political affiliation. On the other hand, Cohen (1986) found that the Commissioners employed by the broadcast industry in fact were less supportive of the broadcast industry. However, Cohen found some evidence that those Commissioners increased their support for the broadcast industry during their last term in office. This paper complements these findings by studying the effect of revolving doors on legislators' behavior.

\section{Ethics Rules}

Federal conflict-of-interest law (18 U.S.C. $§ 201)$ prohibits any public official from accepting anything of value in return for being induced to do or omit to do any official act. The House and the Senate as well as the executive branch have their own ethics regulations, so that members of Congress and government agencies do not cross this line. The most significant revision to the post-congressional restrictions was the Ethics Reform Act of 1989, which allowed former Representatives to accept a lobbying position immediately after leaving Congress but prohibited them from making direct lobbying contacts with their former colleagues for one year after leaving Congress.

However, these restrictions are poorly enforced because of a series of sidesteps, exceptions, 
and evasions. For instance, the cooling-off period applies only to making a direct contact. As a result, former public officials can simply ask other lobbyists to make the contact and act as supervisors for the lobbying campaign. Negotiation of future employment while in office is also common despite the potential conflict of interest. Although the ethics rule suggests recusal from official business where a conflict of interest occurs, internal monitoring activity is rarely observed unless some scandal is uncovered. Moreover, the House rules are more lax than the Senate rules.

With the advent of the Lobbying Disclosure Act of 1995 and the Technical Amendments Act of 1998, which imposed and clarified lobbyist registration and reporting requirements, it became easier to produce a reliable list of former members of Congress who became lobbyists. One issue is that the initial compliance to the disclosure law was arguably low until the 1998 Technical Amendment Act became law. Because incorrect classifications can dilute the results, I did not include the 104th Congress (1995-1996) in the sample. Overall, the institutional background seems to support the research design that correlates members' legislative activity and their lobbying employment.

\section{Empirical Framework}

The basic regression equation is a probit model in which the dependent variable is an indicator variable for post-congressional lobbying employment, which estimates the conditional probability of a member becoming a lobbyist upon leaving Congress. As mentioned before, one concern is that there could be a sample selection problem if, say, members with above average abilities tend to retire voluntarily whereas those with below average abilities tend to 
lose their re-election bids. That is, electorally secure legislators tend to have longer political careers and reach their retirement age while in office. Hence, they may be able to choose to retire only when lobbying job offers are forthcoming or the prospect of future employment looks strong.

On the other hand, members who are electorally insecure face low re-election probabilities, and when they are voted out they have the additional weight of having lost. Thus, only the ones with very attractive profiles may be able to secure post-congressional lobbying employment. For instance, they may have to sell their experience or expert knowledge gained from serving on a powerful committee(s), and to the extent that lobbying firms tend to serve mostly corporate clients they may also need to show a conservative identification to appear attractive to their potential employers. On the other hand, it is not straightforward whether electorally insecure members would change their voting behavior simply assuming that they will not be re-elected.

Heckman (1979) first proposed that this type of selection bias can be corrected for by using a two-step procedure. Further, using doubly truncated means, Heckman's original selection model has been adapted to correct for the selection bias in running separate regressions based on subgroup categories (see, e.g., Idson and Feaster 1990). This literature suggests that, in the first stage, a probit model of retirement decision is estimated, and truncated means for each individual are computed. ${ }^{6}$ In the second stage, regressions are run for each subgroup including the truncated means as an additional regressor in order to provide selection-corrected estimates of the effects of explanatory variables on the likelihood

\footnotetext{
${ }^{6}$ That is, $\lambda_{i}=\phi(X b) / \Phi(X b)$ for the retirement group and $\lambda_{i}=-\phi(X b) /(1-\Phi(X b))$ for the voted-out group.
} 
of landing a lobbying job.

I argue that a member's term-limit pledge can be used as an instrument for retirement decisions in the first-stage estimation. Although there is no mandatory limit on the number of terms that members of Congress can serve, several congressional candidates pledged to self-limit their own terms if elected to Congress, and some of these informal pledges started to be binding from year 2000. Ultimately, some members kept their promise and stepped down, whereas others broke their pledge and sought re-election. Given the amount of public pressure and campaigning against the pledge breakers, the term-limit pledge is no doubt an important factor in leaving Congress without seeking re-election. On the other hand, it seems less likely that the term-limit pledge a candidate made prior to getting elected is correlated with the lobbying employment conditional upon leaving Congress in the future. ${ }^{7}$

In the second-stage estimation of lobbying employment outcome, the main hypotheses is that, holding other factors constant, ideologically more conservative members are more likely to become lobbyists. This is because the vast majority of lobbying expenditures come from corporate clients. According to the Center for Responsive Politics, lobbying expenditures by trade unions collectively comprised only 1.4 percent of total spending in 2005 . Even if we include ideological, single-issue lobbying in this category, this proportion remains only at 7.8 percent. This does not mean that some center-leftists cannot lobby on behalf of unions, but those organizations tend to pay much less than what big companies spend to hire top lobbyists. ${ }^{8}$ So long as ex-members respond to financial incentives, the general

\footnotetext{
${ }^{7}$ That is, given that many congressional hopefuls made term-limit pledges to increase their chance of winning, it is not necessarily the case that those candidates who want to serve longer in Congress would decline to make such pledges (e.g., they can break their pledges later on).

${ }^{8}$ Some of the top lobbyists from the Democratic Party, such as Sen. John Breaux (D-LA), Rep. Thomas Downey (D-NY), Rep. Victor Fazio (D-CA), and Rep. Richard Gephardt (D-MO), who used to represent
} 
trend is predicted to be a positive association between conservative voting and lobbying employment.

Another possibility, as suggested by Butler and Sovey (2010), is that lobbying firms may try to hire moderate party members who can influence the median voter on the floor. Butler and Sovey argue that the access theory or the informational lobbying hypothesis (e.g., Austen-Smith 1995) suggests that former members who are similar to sitting legislators have the best chance to influence them and thus can help a bill pass on the floor. If this is true, then the lobbying firms would want to hire ideologically moderate members of Congress from either party. These two hypotheses, operationalized by location and distance from the median score in Congress, may be viewed as complementary rather than alternatives to each other. Ultimately, which of these two forces is stronger seems to be an empirical question.

There are a number of other explanations for the revolving-door lobbyists. One hypothesis is that the lobbying industry hires those who possess human capital in the form of personal networks and legislative expertise. As Salisbury et al. (1989) suggest, the goodold-boy network suggests that lobbying success depends heavily upon personal contacts and maintaining personal relationships with officials, so that when asked to do things for the benefit of the lobbyist's clients they will be inclined to respond favorably. The question is then how to measure such personal networks. Complete and reliable data on a truly personal network seem to be unknown in the literature and indeed would be difficult to obtain.

However, if a personal network is formed in Congress based on the give and take of legislative support, bill co-sponsorship data could provide a good proxy for such relationships. That is, to the extent that co-sponsoring others' bills can be considered as doing them the working class, now represent America's largest companies as lobbyists. 
favors, a member's outward co-sponsorship can represent how well that member's reciprocal requests would be received by former colleagues. Thus, outward co-sponsorship measures are expected to be positively correlated with lobbying. Similarly, a member's inward cosponsorship indicates the amount of support that the member received from colleagues and thus could measure the member's informal leadership, which is also expected to be positively correlated with lobbying.

In a similar account, members who are elected to a formal leadership position or appointed as a member of powerful committees may have more influence on other members as well as set the future agenda for Congress or congressional committees. The experience and expertise of such members could make them attractive to potential employers and thus is expected to be positively correlated with lobbying. Party leadership and committees serve different functions, but here the purpose is to use them as a proxy to identify those who are in a more influential position than those who are not. If dummy variables are used for each committee and leadership position separately, then the estimation would not be reliable due to the small number of such cases.

On the other hand, the number of terms served in Congress represents a form of general human capital. That is, the more terms a legislator serves in Congress, the more knowledgeable that member becomes about the legislative or political process in general. As long as the lobbying firms value such broad experience and insights, the length of tenure in Congress would be positively correlated with lobbying employment. Members may also try to signal their productivity to potential employers by introducing more pieces of legislation. However, it is probably not so much the quantity of proposed legislation but the content of legislation that matters; thus, it is unclear how the number of bills sponsored would be correlated with 
lobbying employment.

As Herrick and Nixon (1996) hypothesized, legislators who desire a post-congressional lobbying career may also change their behavior in their last term to increase their appeal to potential employers. Hence, I include changes in the members' voting records, bill sponsorship activity, and co-sponsorship counts in their last terms compared to their second-to-last terms in office. This would provide evidence on whether and how members are likely to change their behavior to increase their marketability. However, such opportunistic behavior is not so straightforward for those who would like to hold on to their seat first and foremost because vulnerable members are particularly unlikely to change their voting behavior to please their constituents.

Finally, I control for the members' ages. Some older members may retire and choose not to work, whereas others may retire to take a high paying job before permanent retirement. Thus, the direction of the association is uncertain. On the other hand, members from Maryland might be more willing to work as a lobbyist than a member from California, so I control for the flight time from a member's home to Washington, DC. I also include a Republican dummy because the Republican party won all the elections during the sample period, and the lobbying firms may have more demand for majority party members. Further, the K Street Project pressured lobbying firms to hire Republicans, so there may be a direct, level effect of party affiliation. ${ }^{9}$

Another, yet implausible possibility is that retiring members do not plan ahead their

\footnotetext{
${ }^{9}$ The K Street Project was launched shortly after the 1994 elections by Republican leaders such as Tom DeLay and GOP advisors such as Grover Norquist. The campaign was to place Republican affiliates in high level corporate and industry lobbyist jobs and oust Democrats. Republican leaders held meetings with business executives and lobbyists to pressure them and vetted the hiring decisions of major lobbyists (VandeHei and Eilperin 2003). The project started to wane in 2004.
} 
career choices after serving. If this is the case, then former legislators only think about pursuing a lobbying career after retiring, so their legislative behavior would not be affected by the prospect of lobbying employment. To show that retirement itself is not responsible for the lobbying employment, I start with a basic, pooled-sample regression assuming the usual conditional independence as well as the linear mean function, where the only source of omitted variables is the set of observed covariates. As a robustness check, I also estimate the average treatment effect of voluntary retirement using a propensity score matching estimator with caliper restrictions. The main advantage of matching is that it allows for heterogeneous effects and avoids potential misspecification of conditional mean function.

In order to quantify separate contributions of group differences in measured characteristics and estimated coefficients at the end, I apply a nonlinear decomposition technique commonly attributed to Blinder (1973) and Oaxaca (1973). ${ }^{10}$ That is, the observed differences in predicted probabilities between the two groups can be divided into variations that are attributable to differences in the characteristics of the members (the "endowments effects"), differences in the treatment of these characteristics (the "coefficients effects"), and an unexplained portion of the differential. This can answer the question of whether potential employers have different evaluation criteria or naturally discriminate when they are looking to hire former Congressmen.

\footnotetext{
${ }^{10}$ Intuitively, if the probit index from the two groups are $X_{A} b_{A}$ and $X_{B} b_{B}$, then the difference in the two groups' means can be decomposed as $\bar{X}_{A} \hat{b}_{A}-\bar{X}_{B} \hat{b}_{B}=\left(\bar{X}_{A}-\bar{X}_{B}\right) \hat{b}_{B}+\bar{X}_{B}\left(\hat{b}_{A}-\hat{b}_{B}\right)$ plus an unexplained residual term, where the first term represents the expected change in Group B's mean outcome if Group B had Group A's predictor levels, and the second term measures the expected change in Group B's mean outcome if Group B had Group A's coefficients. See, e.g., Jann (2008) for more details on implementation.
} 


\section{Dataset}

The data set consists of 135 former members of the U.S. House of Representatives for the 105th-108th Congresses (1997-2004) who were eligible to lobby, where eligible members excludes those who became a Senator or took a job in the executive branch within the first three years after leaving Congress. Additionally, the sample does not include those, based on bibliographic research, who left Congress due to serious illness, convictions, or criminal charges because their opportunity to pursue a lobbying career is severely limited, and those who did not serve out a full term or switched their party affiliation during their last term because key explanatory variables are unavailable. ${ }^{11}$

Voluntary retirement is defined as exiting from Congress without running for re-election, the Senate, or a governorship. This divides the sample into 64 voluntary and 71 involuntary exits. For each observation, the dependent variable is an indicator that equals one if the member started working for a lobbying firm or any other organization that is primarily engaged in lobbying within the first three years of departure from Congress. Three years seem to be the upper threshold for most lobbying employment. As a result, two members who started lobbying after five years and one after seven years of leaving Congress were not considered as passing through the revolving doors.

The data set contains the member's personal characteristics and legislative activities during their last term in office. These are the members' voting records as measured by the Americans for Democratic Action (ADA)'s scores, legislative productivity as proxied by the

\footnotetext{
${ }^{11}$ The Center for Responsive Politics has compiled a comprehensive directory of lobbyists, which is current as of September 2006 and includes registered lobbyists under the Lobbying Disclosure Act. I supplemented this source with my own bibliographic research on the members' retirement and post-congressional careers.
} 
number of bills introduced, legislative networks as identified by both inward and outward co-sponsorship, and an indicator of whether the member served on important committees and/or party leadership. Other variables in the dataset include the member's age at exit, term-limit pledge that is due at the time of exit, the number of terms served in Congress, a Republican dummy, and dummy variables for each Congress.

For each member, their ADA scores over the two sessions of their last term in Congress are averaged and time adjusted. ${ }^{12}$ I then constructed two measures of each member's voting records relative to the congressional median. First, the ideological location of each member was calculated by subtracting each member's ADA score from the median. Thus, a higher score in terms of location means a more conservative voting record relative to the median. Second, the absolute distance between a member's ADA score and the congressional median was calculated. Here, the larger the distance, the more ideologically extreme the member's voting record relative to the median.

The ADA scores are not a perfect measure of a legislator's ideology, but they have been extensively used in the literature as a proxy. For instance, ADA scores have been shown to measure business versus labor interests (Grier 1991), as well as producer protection versus consumerism (Weingast and Moran 1983). Because the location and the distance from the median are the same for Republican party members and only differ by the sign for Democratic party members, there is a hidden collinearity problem when these two variables are used at the same time. Thus, in the following analysis, I use these two voting scores one at a time,

\footnotetext{
${ }^{12}$ For comparability across time, I adjusted the ADA scores following the method proposed by Groseclose et al. (1999). This basically standardizes the scores by using estimates of the mean and the dispersion to make them comparable across time. Here, Anderson's (2009) updated estimates were used for the shift and stretch parameters.
} 
so that the collinearity problem does not arise.

There is no established method of how to measure a legislator's good-old-boy network. However, some recent studies used a member's co-sponsorship network as a proxy to measure how well connected a legislator is (e.g., Fowler 2006). In that literature, a few measures have been proposed. For instance, for each inward and outward co-sponsorship, the number of unique legislators who co-sponsored a bill measures the centrality of the sponsoring legislator in the network, and the number of co-sponsor signatures takes into account the frequency of such ties. In this paper, I use a weighted measure that discounts the number of signatures by the number of co-sponsors. ${ }^{13}$

The powerful committees defined in this paper are the Appropriations Committee, the Ways and Means Committee, and the Energy and Commerce Committee. The Rules Committee is sometimes thought to be an important committee as well, but the aforementioned three committees form a distinct top-three group in terms of the total number of revolving door personnel including former staffers, identified to date by the Center for Responsive Politics, and this definition has been used in the literature (e.g., Milyo and Groseclose 1999). As mentioned above, I include the Speaker and the Majority and Minority leaders in this category because they too hold influential positions.

Table 1 provides summary statistics. On average, a departing member served six terms in Congress, introduced 17 bills in the last term, and is 57-years old. Four out of 10 members served on powerful committees, and the sample consists of roughly equal proportions of Republicans and Democrats. Overall, 45 percent of the 135 former Representatives in the

\footnotetext{
${ }^{13}$ The qualitative results in this paper remain unchanged if unique or total co-sponsorship measures are used instead of the weighted measure. Co-sponsorship data were obtained from James H. Fowler $<$ http://jhfowler.ucsd.edu/cosponsorship.htm $>$.
} 
sample stepped into a lobbying career. A comparison of the means shows that the voluntary retirement group has a 53 percent rate of pursuing a lobbying career, whereas the voted-out group has a 38 percent rate. This difference is marginally significant. That is, those who choose to retire seem to have a higher unconditional probability of lobbying than those who lose re-election.

The explanatory variables are grouped into three categories, that is, those describing the legislators' characteristics, their legislative behavior in the last term, and changes in legislative behavior compared to the previous term. That is, the variables in the third category measure the differences between the legislator's last and the second-to-last term in

Congress. There are some statistically significant differences between the characteristics of the two groups. For instance, those who voluntarily retire tend to be older and have served more terms on average than those who are voted out. The term-limit pledge variable shows that the proportion of those who self-imposed a term limit is higher for the retirement group than for the voted-out group.

\section{Results}

In this section, I report the estimation results based on two sets of covariates. In both specifications, the covariates are grouped into the three components (i.e., legislator characteristics; legislative behavior; and changes in legislative behavior). The difference is that in Tables 2 and 4, I use the member's ideological location to test the hypothesis that lobbying firms demand relatively more conservative members to serve the need of mostly corporate clients. In Tables 3 and 5, I use the distance from the median, instead of the location, to compare the 
model fit as well as to test the hypothesis that lobbying firms value ideologically moderate members of the Congress whose preferences are similar to the median voter (Austen-Smith 1995).

Column (1) of Table 2 reports pooled profit estimates, which assumes that selection due to unobservable factors is not relevant and also that the two groups are homogenous. The retirement dummy is marginally significant at the 10 percent level. The signs of other significant coefficients appear consistent with the hypotheses. For instance, powerful committee assignment, the number of terms served, and conservative voting records (relative to the median) are all significant and positively correlated with lobbying employment, whereas age and the Republican dummy are negatively associated with it. Further, a change in the last term towards more conservative voting is negatively associated with lobbying.

The next three columns estimate the treatment effects of voluntary retirement on lobbying employment. This can answer the question of whether retirement is responsible for lobbying, which in other words would mean that lobbying was not planned before retirement. To do so, column (2) estimates a propensity score based on all covariates and predicts the probability of voluntary retirement. Column (2) shows that an older age and a decrease in the number of bills sponsored mainly predict a member's retirement decision at the conventional level. There is sufficient overlap in the distributions of the estimated propensity scores between the two groups, so the matching on estimated linear propensity scores performs well (Rubin and Thomas 1996)

Columns (3) and (4) show matching estimates of the retirement effect with different tolerance levels. In column (3), with a tighter caliper bound, the treatment effect of voluntary retirement drops approximately 18 percent, and the coefficient is no longer significant at 
the 10 percent level. In column (4), when the caliper bound is relaxed, the retirement coefficient decreases even further. This suggests that lobbying employment is unlikely to be an afterthought of the retirees because the probability of lobbying is not significantly higher for those who voluntarily retire. However, this argument is not conclusive because the conditional independence assumption to identify a treatment effect is often implausible, and many of the covariates are not known.

Table 3 presents the analogous results using the distance, instead of the location, from the congressional median. In column (1), more ideologically moderate members seem marginally more likely to lobby, but the moderation in voting in the last term relative to the secondto-last term is not correlated with lobbying. In column (2), in predicting the probability of retirement, the difference is that the Republican dummy and a movement away from the congressional median are additionally associated with voluntary retirement. In terms of treatment effect, similar to the previous results, both estimates in columns (3) and (4) are not statistically significant, which suggests that based on observable covariates retirement is not a trigger for lobbying.

The analysis thus far suggests that such factors as committee assignment, experience, age, and conservative voting generally seem to matter the most. One pitfall, however, is that the above analysis ignores selection on unobservables, and by assumption it treats the two groups of legislators in the same way. Uncovering the selection bias and discerning the difference between the two groups can shed light on policy implications, to which we turn below. As explained above, the identification is helped by the inclusion of the term-limitpledge variable, which is excluded from the outcome equation.

Table 4 shows the estimates of the selection model by legislator group. Column (1) reports 
the estimates of the first-stage probit equation for retirement decision. The coefficient on the term-limit-pledge variable is significant and positive, which suggests that public pressure and a campaign against pledge breakers were indeed important factors for those legislators to keep their promises. Other significant variables for predicting retirement include age and tenure. It also appears that departing members sponsored a larger number of bills but received less co-sponsorship support in their last term. The signs of these coefficients are consistent with those in column (2) of Table 2 ; however, the coefficients are now more precisely estimated.

Columns (2) and (3) of Tables 4 report the main regression results, where the selection bias due to unobservable factors is corrected for by including truncated means calculated from the first-stage probit equation reported in column (1). Because the truncated means are positive (negative) for the retirees (election losers), the statistically significant, positive coefficient on the selection term in column (2) means a significantly higher predicted probability of lobbying for the retirement group. This contrasts with the previous results when only observable covariates were considered. On the other hand, the selection term for the voted-out group is statistically insignificant implying that losing (re)election does not decrease lobbying employment.

The estimation results in columns (2) and (3) tell us that the underlying relationship between the covariates and lobbying employment differs significantly depending on whether a legislator voluntarily retired or was voted out. That is, for the retirees, the length of congressional tenure and a decrease in conservative voting scores in the last term increase the probability of lobbying at the 1 percent level, followed by a decrease in the number of bills sponsored at the 5 percent level. In contrast, for those who were voted out, important committee assignment and conservative voting scores are positively correlated, and the Re- 
publican dummy negatively associated with lobbying at the 1 percent level, followed by the flight time to Washington, DC.

These two sets of significant predictors are mutually exclusive. Election losers seem to need an attractive profile demonstrated by membership of a powerful committee(s) and conservative voting scores. In this group of legislators, a Republican party member is in fact less likely to become a lobbyist, holding other factors constant, implying that despite the K Street Project the labor market for lobbyists did not necessarily confer advantages to Republican members. Further, none of the co-sponsorship network variables seems to matter for this group of legislators. In summary, lobbying firms seem to value expert knowledge gained from serving on the powerful committee(s) and conservative voting records when a legislator is voted out of office.

On the other hand, specific knowledge and ideological positions do not seem to play an important role for retiring members. Instead, employers seem to value general knowledge and experience as proxied by the length congressional tenure. Looking at column (2), for this group of legislators, there is some evidence that they engage in legislative shirking in their last term in office. That is, a movement towards less conservative voting as well as a decrease in the number of bills sponsored in their last term in office predict a higher probability of lobbying employment after serving. This is consistent with the idea that those who did not face re-election pressure have more freedom to change their voting behavior and slow down legislative productivity.

As Butler and Sovey (2010) elaborated, another possibility is that moderate members of Congress are more valuable to lobbying firms. Butler and Sovey compared members with moderate and extreme voting records, and found that moderate members are more 
likely to become lobbyists after leaving Congress (where this result was only marginally significant with a p-value near 0.10). Despite a number of differences in their specifications and those in this paper, I test their basic hypothesis by using the ideological distance from the congressional median and present the estimation results in Table 5.

In column (3) of Table 5, for the voted-out group, there is some evidence that ideologically moderate members are more likely to become lobbyists (which is also only marginally significant) because the coefficient on the distance measure is negative. On the other hand, column (2) in this table shows that for the retirement group an increase rather than a decrease in the measured distance from the median in the last term is positively associated with lobbying at the 1 percent level, whereas the rest of the coefficient estimates are generally consistent with those in Table 4. Further, the model fit of the outcome equation, as measured by pseudo $R^{2}$, is lower with the distance than with the location variable. Therefore, the data seem to prefer the former hypothesis.

The main results in Table 4 can be interpreted as follows. In the literature on lobbying campaigns targets, some authors find that interest groups tend to lobby mainly their legislative allies (e.g., Bauer et al. 1963; Milbrath 1963), whereas others argue that interest groups may target opposing, undecided members of Congress (e.g., Austen-Smith and Wright 1994). Similarly, the reason why having a more conservative voting record predicts a future in lobbying may be that among those who generally support conservative, corporate interests (i.e., Republicans), lobbying firms may look for someone with a strong ideological commitment who can lead and expand their agenda, whereas lobbying firms may want to hire moderates from those in the opposite spectrum (i.e., Democrats) who can cooperate with them and persuade the median voter in Congress. 
Another robust finding is that the legislative activities measured by bill sponsorship and co-sponsorship are not significant predictors of lobbying employment, although for the retirement group those who become lobbyists tend to significantly reduce the number of bills they sponsor in their last term. This suggests that those who pass through the revolving doors tend not to be the most productive members or possess a strong network with other members. This may be because these covariates are indeed unimportant for Representativeturned-lobbyists. This is in fact consistent with findings by Milbrath (1963) and Salisbury et al. (1989). Based on surveys of Washington lobbyists, these authors showed that a knowledge of subject matters and legislative processes were more often deemed important than who was known in the legislative and executive branches.

Finally, I formally test the significance of the difference between both groups of legislators. Table 6 shows the decomposition of the probability differential attributable to differences in characteristics and estimated coefficients for the specifications considered in Tables 4 and 5. The respective contribution of the three explanatory variable groups to the likelihood of lobbying are reported. The selection term is not included here because of difficulty in interpreting. The first row of each subpanel shows that overall only the coefficients effect (i.e., differences in estimated coefficients) is statistically significant. This implies that different evaluations of former members of Congress by potential employers is the main reason for the above empirical findings rather than the differences in the observed characteristics or behavior of those legislators. 


\section{Conclusion}

The fact that some members of Congress seem to care about lucrative careers as lobbyists after serving is of critical public policy concern. This paper lays out some basic empirical connections between post-congressional lobbying employment and legislative activities as well as legislator characteristics. The model took into account the nonrandom selection issue and allowed for different underlying structure for voted-out and retiring members of Congress. I found that there is a strong selection bias that works in favor of the retiring members of Congress, suggesting that re-election pressure is not effective in restraining their behavior.

The main empirical findings are that for those who were voted out the Congress-tolobbying revolving door is associated with powerful committee assignments and conservative voting records. For those who voluntarily retired, however, these mechanisms are largely absent. Instead, congressional tenure and a movement towards less conservative voting are associated with lobbying employment. One limitation of this paper is that the qualitative nature of those behavioral changes is not examined. Future research might investigate the substantive nature of bills sponsored and voted for or against by the revolving-door legislators.

\section{References}

[1] Anderson, Sarah (2009), "Revisiting Adjusted ADA Scores for the U.S. Congress, 19472007," Political Analysis 17(1): 83-88. 
[2] Austen-Smith, David (1995), "Campaign Contributions and Access," American Political Science Review 89(3): 566-581.

[3] Austen-Smith, David, and John Wright (1994), "Counteractive Lobbying," American Journal of Political Science 38(1): 25-44.

[4] Bauer, Raymond, Ithiel Pool, and Lewis Dexter (1963), American Business and Public Policy: The Politics of Foreign Trade, New York, NY: Atherton Press.

[5] Bertrand, Marianne, Matilde Bombardini, and Francesco Trebbi (2011), "Is It Whom You Know or What You Know? An Empirical Assessment of the Lobbying Process," NBER Working Paper No. 16765.

[6] Blanes i Vidal, Jordi, Mirko Draca, and Christian Fons-Rosen (2010), "Revolving Door Lobbyists," Manuscript, London School of Economics and Political Science.

[7] Blinder, Alan (1973), "Wage Discrimination: Reduced Form and Structural Variables." Journal of Human Resources 8(4): 436-455.

[8] Borders, Rebecca, and C. Dockery (1995), Beyond the Hill: a directory of Congress from 1984 to 1993: where have all the members gone? Lanham, MD: University Press of America.

[9] Butler, Daniel, and Allison Sovey (2010), "Do Lobbying Firms Target Legislators Key to the Legislative Process? Evidence from the Revolving Door," Manuscript, Yale University. 
[10] Cohen, Jeffrey (1986), "The Dynamics of the "Revolving Door" on the FCC," American Journal of Political Science 30(4): 689-708.

[11] Diermeier, Daniel, Michael Keane, and Antonio Merlo (2005), "A Political Economy Model of Congressional Careers," American Economic Review 95(1): 347-373.

[12] Fowler, James (2006), "Connecting the Congress: A Study of Cosponsorship Networks," Political Analysis 14(4): 456-487.

[13] Gely, Rafael, and Asghar Zardkoohi (2001), "Measuring the Effects of Post-Government Employment Restrictions," American Law and Economics Review 3(2): 288-301.

[14] Gormley, William (1979), "A Test of the Revolving Door Hypothesis at the FCC," American Journal of Political Science 23(4): 665-683.

[15] Grier, Kevin (1991), "Congressional Inłuence on U.S. Monetary Policy: An Empirical Test," Journal of Monetary Economics 28(2): 201-220.

[16] Groseclose, Timothy, Steven Levitt, and James Snyder (1999), "Comparing Interest Group Scores across Time and Chambers: Adjusted ADA Score for the U.S. Congress," American Political Science Review 93(1): 33-50.

[17] Groseclose, Timothy, and Keith Krehbiel (1994), "Golden Parachutes, Rubber Checks, and Strategic Retirements from the 102nd House," American Journal of Political Science 38(1): 75-99. 
[18] Hall, Richard, and Robert van Houweling (1995), "Avarice and Ambition in Congress: Representatives' Decisions to Run or Retire from the U.S. House," American Political Science Review 89(1): 121-136.

[19] Heckman, James (1979), "Sample Selection Bias as a Specification Error," Econometrica 47(1): 153-161.

[20] Herrick, Rebekah, and David Nixon (1996), "Is There Life after Congress? Patterns and Determinants of Post-Congressional Careers," Legislative Studies Quarterly 21(4): $489-499$.

[21] Idson, Todd, and Daniel Feaster (1990), "A Selectivity Model of Employer-Size Wage Differentials," Journal of Labor Economics 8(1): 99-122.

[22] Jann, Ben (2008), "The Blinder-Oaxaca Decomposition for Linear Regression Models," Stata Journal 8(4): 453-479.

[23] Kiewiet, D. Roderick, and Langche Zeng (1993), "An Analysis of Congressional Career Decisions, 1947-1986" American Political Science Review 87(4): 928-941.

[24] Leal, David (2002), "Home Is Where the Heart Is: Congressional Tenure, Retirement, and the Implications for Representation," American Politics Research 30(3): 265-284.

[25] Milbrath, Lester (1963), The Washington lobbyists, Chicago, IL: Rand McNally.

[26] Milyo, Jeffrey, and Timothy Groseclose (1999), "The Electoral Effects of Incumbent Wealth," Journal of Law and Economics 42(2): 699-722. 
[27] Oaxaca, Ronald (1973), "Male-Female Wage Differentials in Urban Labor Markets," International Economic Review 14(3): 693-709.

[28] Public Citizen (2005), Congressional Revolving Doors: The Journey from Congress to K Street, Washington, DC: Public Citizen.

[29] Rubin, Donald, and Neal Thomas (1996), "Matching Using Estimated Propensity Scores: Relating Theory to Practice," Biometrics 52(1): 249-264.

[30] Salisbury, Robert, Paul Johnson, John Heinz, Edward Laumann, and Robert Nelson (1989), "Who You Know versus What You Know: The Uses of Government Experience for Washington Lobbyists," American Journal of Political Science 33(1): 175-195.

[31] VandeHei, Jim, and Juliet Eilperin (2003), "Targeting Lobbyists Pays Off For GOP," Washington Post, June 26, 2003.

[32] Weingast, Barry, and Mark Moran (1983), "Bureaucratic Discretion or Congressional Control? Regulatory Policymaking by the Federal Trade Commission," Journal of Political Economy 91(5): 765-800.

[33] Zeigler, Harmon, and Michael Baer (1968), "The Recruitment of Lobbyists and Legislators," Midwest Journal of Political Science 12(4): 493-513. 


\begin{tabular}{|c|c|c|c|c|}
\hline & $\begin{array}{c}\text { Full } \\
\text { Sample }\end{array}$ & $\begin{array}{l}\text { Voted-out } \\
\text { Subsample }\end{array}$ & $\begin{array}{l}\text { Retirement } \\
\text { Subsample }\end{array}$ & $\begin{array}{l}\text { Differences in } \\
\text { Means, p-value }\end{array}$ \\
\hline Lobbying employment & $\begin{array}{c}0.452 \\
(0.500)\end{array}$ & $\begin{array}{c}0.380 \\
(0.489)\end{array}$ & $\begin{array}{c}0.531 \\
(0.503)\end{array}$ & 0.078 \\
\hline \multicolumn{5}{|l|}{ Legislator characteristics: } \\
\hline Republican & $\begin{array}{c}0.556 \\
(0.499)\end{array}$ & $\begin{array}{c}0.493 \\
(0.504)\end{array}$ & $\begin{array}{c}0.625 \\
(0.488)\end{array}$ & 0.123 \\
\hline Committee & $\begin{array}{c}0.385 \\
(0.488)\end{array}$ & $\begin{array}{c}0.324 \\
(0.471)\end{array}$ & $\begin{array}{c}0.453 \\
(0.502)\end{array}$ & 0.124 \\
\hline Number of terms & $\begin{array}{c}5.911 \\
(4.095)\end{array}$ & $\begin{array}{c}4.352 \\
(3.458)\end{array}$ & $\begin{array}{c}7.641 \\
(4.074)\end{array}$ & 0.000 \\
\hline Age at exit & $\begin{array}{c}56.59 \\
(10.36)\end{array}$ & $\begin{array}{l}52.04 \\
(8.240)\end{array}$ & $\begin{array}{c}61.64 \\
(10.17)\end{array}$ & 0.000 \\
\hline Flight time to DC & $\begin{array}{c}100.5 \\
(76.97)\end{array}$ & $\begin{array}{l}98.92 \\
(71.71)\end{array}$ & $\begin{array}{c}102.2 \\
(82.94)\end{array}$ & 0.806 \\
\hline \multicolumn{5}{|l|}{ Legislative behavior: } \\
\hline Location relative to the median & $\begin{array}{l}-7.766 \\
(35.16)\end{array}$ & $\begin{array}{l}-11.72 \\
(34.78)\end{array}$ & $\begin{array}{l}-3.375 \\
(35.34)\end{array}$ & 0.169 \\
\hline Distance from the median & $\begin{array}{c}31.72 \\
(16.83)\end{array}$ & $\begin{array}{c}32.52 \\
(16.62)\end{array}$ & $\begin{array}{c}30.84 \\
(17.16)\end{array}$ & 0.564 \\
\hline Bill sponsorship & $\begin{array}{c}17.19 \\
(12.08)\end{array}$ & $\begin{array}{c}16.18 \\
(11.13)\end{array}$ & $\begin{array}{c}18.31 \\
(13.06)\end{array}$ & 0.308 \\
\hline Outward cosponsorship & $\begin{array}{c}9.603 \\
(7.387)\end{array}$ & $\begin{array}{c}10.56 \\
(8.825)\end{array}$ & $\begin{array}{c}8.539 \\
(5.229)\end{array}$ & 0.112 \\
\hline Inward cosponsorship & $\begin{array}{c}10.24 \\
(7.383)\end{array}$ & $\begin{array}{c}10.03 \\
(7.304)\end{array}$ & $\begin{array}{c}10.48 \\
(7.521)\end{array}$ & 0.721 \\
\hline \multicolumn{5}{|l|}{ Changes in legislative behavior: } \\
\hline Changes in location rel. to the med. & $\begin{array}{l}-1.382 \\
(10.50)\end{array}$ & $\begin{array}{l}-1.456 \\
(11.08)\end{array}$ & $\begin{array}{l}-1.311 \\
(10.00)\end{array}$ & 0.939 \\
\hline Changes in distance from the med. & $\begin{array}{c}0.902 \\
(10.55)\end{array}$ & $\begin{array}{c}0.137 \\
(11.18)\end{array}$ & $\begin{array}{c}1.632 \\
(9.955)\end{array}$ & 0.431 \\
\hline Changes in bill sponsorship & $\begin{array}{c}2.384 \\
(10.62)\end{array}$ & $\begin{array}{c}3.951 \\
(8.057)\end{array}$ & $\begin{array}{c}0.891 \\
(12.46)\end{array}$ & 0.107 \\
\hline Changes in outward cosponsorship & $\begin{array}{c}0.887 \\
(4.001)\end{array}$ & $\begin{array}{c}1.314 \\
(4.449)\end{array}$ & $\begin{array}{c}0.480 \\
(3.510)\end{array}$ & 0.246 \\
\hline Changes in inward cosponsorship & $\begin{array}{c}1.656 \\
(6.689)\end{array}$ & $\begin{array}{c}2.557 \\
(5.334)\end{array}$ & $\begin{array}{c}0.797 \\
(7.709)\end{array}$ & 0.142 \\
\hline $\begin{array}{l}\text { Instrument for retirement: } \\
\text { Term limit pledge due }\end{array}$ & $\begin{array}{c}0.096 \\
(0.296)\end{array}$ & $\begin{array}{c}0.042 \\
(0.203)\end{array}$ & $\begin{array}{c}0.156 \\
(0.366)\end{array}$ & 0.025 \\
\hline Sample size & $135(125)^{\mathrm{a}}$ & $71(61)^{a}$ & 64 & \\
\hline
\end{tabular}

Table. 1: DESCRIPTIVE STATISTICS

Mean values are reported with standard deviations in the parentheses. In the last column, p-values are from two-tailed tests.

${ }^{a}$ For changes in legislative behavior, the sample size of the voted-out group is smaller because ten Representatives served only one term. 


\begin{tabular}{|c|c|c|c|c|}
\hline & $\begin{array}{c}\text { Full-sample } \\
\text { Probit } \\
\text { (1) }\end{array}$ & $\begin{array}{l}\text { Propensity } \\
\text { Score } \\
(2) \\
\end{array}$ & $\begin{array}{c}\text { Caliper } \\
\text { Matching } \\
(3)\end{array}$ & $\begin{array}{c}\text { Caliper } \\
\text { Matching } \\
(4)\end{array}$ \\
\hline Retirement & $\begin{array}{l}0.211^{\star} \\
(0.114)\end{array}$ & & $\begin{array}{c}0.172 \\
(0.250)\end{array}$ & $\begin{array}{c}0.140 \\
(0.220)\end{array}$ \\
\hline \multicolumn{5}{|l|}{ Legislator characteristics: } \\
\hline Republican & $\begin{array}{c}-0.747^{\star *} \\
(0.196)\end{array}$ & $\begin{array}{c}0.562 \\
(0.295)\end{array}$ & & \\
\hline Committee & $\begin{array}{c}0.310^{\star \star \star \star} \\
(0.108)\end{array}$ & $\begin{array}{l}-0.071 \\
(0.115)\end{array}$ & & \\
\hline Number of terms & $\begin{array}{c}0.060^{\star \star \star \star ~} \\
(0.018)\end{array}$ & $\begin{array}{l}0.035^{\star} \\
(0.020)\end{array}$ & & \\
\hline Age at exit & $\begin{array}{c}-0.022^{\text {*** }} \\
(0.007)\end{array}$ & 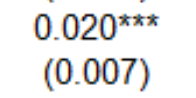 & & \\
\hline Flight time to DC & $\begin{array}{c}0.001 \\
(0.001)\end{array}$ & $\begin{array}{c}0.000 \\
(0.001)\end{array}$ & & \\
\hline \multicolumn{5}{|l|}{ Legislative behavior: } \\
\hline Location relative to the median & 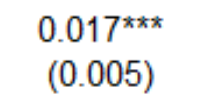 & $\begin{array}{l}-0.006 \\
(0.005)\end{array}$ & & \\
\hline Bill sponsorship & $\begin{array}{c}0.002 \\
(0.012)\end{array}$ & $\begin{array}{l}0.021^{*} \\
(0.012)\end{array}$ & & \\
\hline Outward cosponsorship & $\begin{array}{c}0.008 \\
(0.011)\end{array}$ & $\begin{array}{l}-0.017 \\
(0.012)\end{array}$ & & \\
\hline Inward cosponsorship & $\begin{array}{c}0.006 \\
(0.018)\end{array}$ & $\begin{array}{l}-0.034^{\star} \\
(0.019)\end{array}$ & & \\
\hline \multicolumn{5}{|l|}{ Changes in legislative behavior: } \\
\hline Changes in location rel. to the med. & $\begin{array}{c}-0.016^{\star *} \\
(0.006)\end{array}$ & $\begin{array}{l}-0.002 \\
(0.006)\end{array}$ & & \\
\hline Changes in bill sponsorship & $\begin{array}{l}-0.010 \\
(0.013)\end{array}$ & $\begin{array}{c}-0.027^{\star *} \\
(0.014)\end{array}$ & & \\
\hline Changes in outward cosponsorship & $\begin{array}{l}-0.010 \\
(0.020)\end{array}$ & $\begin{array}{c}0.002 \\
(0.021)\end{array}$ & & \\
\hline Changes in inward cosponsorship & $\begin{array}{c}0.006 \\
(0.020)\end{array}$ & $\begin{array}{l}0.041^{\star} \\
(0.022)\end{array}$ & & \\
\hline Congress dummies & Yes & Yes & & \\
\hline Pseudo $R^{2}$ & 0.263 & 0.255 & & \\
\hline Tolerance level & & & 0.01 & 0.02 \\
\hline On support & & & 90 & 104 \\
\hline Off support & & & 35 & 21 \\
\hline
\end{tabular}

Table. 2: PROBIT AND MATCHING MODELS I

Columns (1) and (2) report marginal effects at the mean, where the dependent variable is one for lobbying and retirement, respectively. Standard errors are in the parentheses, and likelihood ratio tests are reported. Columns (3) and (4) report the average treatment effect on the treated, where the outcome variable is one for lobbying, and bootstrapped standard errors are reported.

*** Significant at 1 percent, ** Significant at 5 percent, ${ }^{*}$ Significant at 10 percent. 


\begin{tabular}{|c|c|c|c|c|}
\hline & $\begin{array}{c}\text { Full-sample } \\
\text { Probit } \\
\text { (1) }\end{array}$ & $\begin{array}{l}\text { Propensity } \\
\text { Score } \\
(2) \\
\end{array}$ & $\begin{array}{c}\text { Caliper } \\
\text { Matching } \\
(3)\end{array}$ & $\begin{array}{c}\text { Caliper } \\
\text { Matching } \\
(4)\end{array}$ \\
\hline Retirement & $\begin{array}{l}0.194^{\star} \\
(0.114)\end{array}$ & & $\begin{array}{c}0.125 \\
(0.253)\end{array}$ & $\begin{array}{c}0.195 \\
(0.230)\end{array}$ \\
\hline \multicolumn{5}{|l|}{ Legislator characteristics: } \\
\hline Republican & $\begin{array}{c}0.057 \\
(0.150)\end{array}$ & $\begin{array}{l}0.339^{\star *} \\
(0.154)\end{array}$ & & \\
\hline Committee & $\begin{array}{l}0.254^{\star \star} \\
(0.106)\end{array}$ & $\begin{array}{l}-0.038 \\
(0.116)\end{array}$ & & \\
\hline Number of terms & 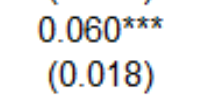 & $\begin{array}{l}0.038^{\star \star} \\
(0.019)\end{array}$ & & \\
\hline Age at exit & $\begin{array}{c}-0.020^{\text {*** }} \\
(0.007)\end{array}$ & 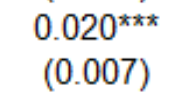 & & \\
\hline Flight time to DC & $\begin{array}{c}0.000 \\
(0.001)\end{array}$ & $\begin{array}{c}0.001 \\
(0.001)\end{array}$ & & \\
\hline \multicolumn{5}{|l|}{ Legislative behavior: } \\
\hline Distance from the median & $\begin{array}{l}-0.008^{*} \\
(0.005)\end{array}$ & $\begin{array}{c}0.004 \\
(0.005)\end{array}$ & & \\
\hline Bill sponsorship & $\begin{array}{c}0.009 \\
(0.011)\end{array}$ & $\begin{array}{l}0.023^{\star \star} \\
(0.012)\end{array}$ & & \\
\hline Outward cosponsorship & $\begin{array}{c}0.004 \\
(0.011)\end{array}$ & $\begin{array}{l}-0.018 \\
(0.012)\end{array}$ & & \\
\hline Inward cosponsorship & $\begin{array}{l}-0.017 \\
(0.018)\end{array}$ & $\begin{array}{l}-0.033^{*} \\
(0.018)\end{array}$ & & \\
\hline \multicolumn{5}{|l|}{ Changes in legislative behavior: } \\
\hline Changes in distance from the med. & $\begin{array}{c}0.003 \\
(0.006)\end{array}$ & $\begin{array}{l}0.010^{*} \\
(0.006)\end{array}$ & & \\
\hline Changes in bill sponsorship & $\begin{array}{l}-0.010 \\
(0.013)\end{array}$ & $\begin{array}{c}-0.030^{* *} \\
(0.014)\end{array}$ & & \\
\hline Changes in outward cosponsorship & $\begin{array}{l}-0.010 \\
(0.020)\end{array}$ & $\begin{array}{c}0.007 \\
(0.021)\end{array}$ & & \\
\hline Changes in inward cosponsorship & $\begin{array}{c}0.023 \\
(0.019)\end{array}$ & $\begin{array}{l}0.040^{*} \\
(0.021)\end{array}$ & & \\
\hline Congress dummies & Yes & Yes & & \\
\hline Pseudo $R^{2}$ & 0.205 & 0.278 & & \\
\hline Tolerance level & & & 0.01 & 0.02 \\
\hline On support & & & 93 & 102 \\
\hline Off support & & & 32 & 23 \\
\hline
\end{tabular}

Table. 3: PROBIT AND MATCHING MODELS II

Columns (1) and (2) report marginal effects at the mean, where the dependent variable is one for lobbying and retirement, respectively. Standard errors are in the parentheses, and likelihood ratio tests are reported. Columns (3) and (4) report the average treatment effect on the treated, where the outcome variable is one for lobbying, and bootstrapped standard errors are reported.

*** Significant at 1 percent, ** Significant at 5 percent, ${ }^{*}$ Significant at 10 percent. 


\begin{tabular}{|c|c|c|c|}
\hline & $\begin{array}{l}\text { First-stage } \\
\text { probit for } \\
\text { retirement } \\
\text { (1) }\end{array}$ & $\begin{array}{l}\text { Representatives } \\
\text { who voluntarily } \\
\text { retired } \\
\text { (2) }\end{array}$ & $\begin{array}{c}\text { Representatives } \\
\text { who were voted } \\
\text { out } \\
\text { (3) }\end{array}$ \\
\hline Term limit pledge due & 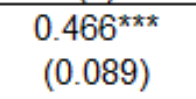 & & \\
\hline \multicolumn{4}{|l|}{ Legislator characteristics: } \\
\hline Republican & $\begin{array}{l}0.638^{*} \\
(0.285)\end{array}$ & $\begin{array}{c}0.885 \\
(0.306)\end{array}$ & $\begin{array}{c}-0.999^{\star \star *} \\
(0.005)\end{array}$ \\
\hline Committee & $\begin{array}{l}-0.033 \\
(0.120)\end{array}$ & $\begin{array}{c}0.223 \\
(0.183)\end{array}$ & $\begin{array}{c}0.688^{\star \star \star *} \\
(0.198)\end{array}$ \\
\hline Number of terms & $\begin{array}{l}0.046^{\star \star} \\
(0.021)\end{array}$ & $\begin{array}{c}0.126^{\star \star \star *} \\
(0.036)\end{array}$ & $\begin{array}{c}0.036 \\
(0.039)\end{array}$ \\
\hline Age at exit & $\begin{array}{c}0.021^{\text {**ᄎ }} \\
(0.007)\end{array}$ & $\begin{array}{l}-0.002 \\
(0.014)\end{array}$ & $\begin{array}{l}-0.016 \\
(0.015)\end{array}$ \\
\hline Flight time to DC & $\begin{array}{c}0.000 \\
(0.001)\end{array}$ & $\begin{array}{l}0.002^{*} \\
(0.001)\end{array}$ & $\begin{array}{l}0.003^{\star \star} \\
(0.001)\end{array}$ \\
\hline \multicolumn{4}{|l|}{ Legislative behavior: } \\
\hline Location relative to the median & $\begin{array}{l}-0.009 \\
(0.006)\end{array}$ & $\begin{array}{l}-0.001 \\
(0.012)\end{array}$ & $\begin{array}{c}0.038^{\text {***}} \\
(0.012)\end{array}$ \\
\hline Bill sponsorship & $\begin{array}{l}0.023^{\star} \\
(0.013)\end{array}$ & $\begin{array}{c}0.020 \\
(0.018)\end{array}$ & $\begin{array}{c}0.031 \\
(0.033)\end{array}$ \\
\hline Outward cosponsorship & $\begin{array}{l}-0.016 \\
(0.013)\end{array}$ & $\begin{array}{l}-0.045 \\
(0.031)\end{array}$ & $\begin{array}{l}-0.007 \\
(0.016)\end{array}$ \\
\hline Inward cosponsorship & $\begin{array}{c}-0.039^{\star \star} \\
(0.020)\end{array}$ & $\begin{array}{l}-0.018 \\
(0.031)\end{array}$ & $\begin{array}{l}-0.004 \\
(0.041)\end{array}$ \\
\hline \multicolumn{4}{|l|}{ Changes in legislative behavior: } \\
\hline Changes in location rel. to the med. & $\begin{array}{l}-0.001 \\
(0.007)\end{array}$ & 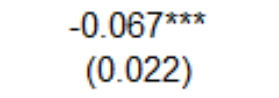 & $\begin{array}{l}-0.013 \\
(0.010)\end{array}$ \\
\hline Changes in bill sponsorship & $\begin{array}{c}-0.030^{\star *} \\
(0.015)\end{array}$ & $\begin{array}{c}-0.052^{\star \star} \\
(0.024)\end{array}$ & $\begin{array}{l}-0.031 \\
(0.026)\end{array}$ \\
\hline Changes in outward cosponsorship & $\begin{array}{l}-0.010 \\
(0.022)\end{array}$ & $\begin{array}{l}-0.018 \\
(0.041)\end{array}$ & $\begin{array}{l}0.075^{\star} \\
(0.042)\end{array}$ \\
\hline Changes in inward cosponsorship & $\begin{array}{l}0.046^{\star \star} \\
(0.023)\end{array}$ & $\begin{array}{l}0.070^{\star} \\
(0.038)\end{array}$ & $\begin{array}{l}-0.002 \\
(0.035)\end{array}$ \\
\hline Selection term & & $\begin{array}{l}1.550^{\star \star \star} \\
(0.472)\end{array}$ & $\begin{array}{c}0.245 \\
(0.367)\end{array}$ \\
\hline Congress dummies & Yes & Yes & Yes \\
\hline Pseudo $R^{2}$ & 0.312 & 0.489 & 0.419 \\
\hline
\end{tabular}

Table. 4: SELECTION MODEL BY GROUP I

Column (1) reports marginal effects at the mean, where the dependent variable is one for retirement. Columns (2) and (3) report marginal effects at the mean, where the dependent variable is one for lobbying. Standard errors are in the parentheses, and likelihood ratio tests are reported.

***Significant at 1 percent, ${ }^{* *}$ Significant at 5 percent, ${ }^{*}$ Significant at 10 percent. 


\begin{tabular}{|c|c|c|c|}
\hline & $\begin{array}{l}\text { First-stage } \\
\text { probit for } \\
\text { retirement } \\
\text { (1) }\end{array}$ & $\begin{array}{l}\text { Representatives } \\
\text { who voluntarily } \\
\text { retired } \\
\text { (2) }\end{array}$ & $\begin{array}{c}\text { Representatives } \\
\text { who were voted } \\
\text { out } \\
\text { (3) }\end{array}$ \\
\hline Term limit pledge due & $\begin{array}{c}0.468^{\star \star \star *} \\
(0.091)\end{array}$ & & \\
\hline \multicolumn{4}{|l|}{ Legislator characteristics: } \\
\hline Republican & $\begin{array}{c}0.237 \\
(0.169)\end{array}$ & $\begin{array}{l}0.460^{\star} \\
(0.249)\end{array}$ & $\begin{array}{l}-0.157 \\
(0.291)\end{array}$ \\
\hline Committee & $\begin{array}{c}0.010 \\
(0.121)\end{array}$ & $\begin{array}{c}0.295 \\
(0.174)\end{array}$ & $\begin{array}{l}0.445^{\star \star *} \\
(0.181)\end{array}$ \\
\hline Number of terms & $\begin{array}{l}0.045^{\star \star} \\
(0.020)\end{array}$ & $\begin{array}{c}0.107^{\star \star \star *} \\
(0.030)\end{array}$ & $\begin{array}{c}0.028 \\
(0.043)\end{array}$ \\
\hline Age at exit & $\begin{array}{c}0.022^{\star * *} \\
(0.007)\end{array}$ & $\begin{array}{c}-0.006 \\
(0.012)\end{array}$ & $\begin{array}{l}-0.000 \\
(0.014)\end{array}$ \\
\hline Flight time to DC & $\begin{array}{c}0.001 \\
(0.001)\end{array}$ & $\begin{array}{c}0.001 \\
(0.001)\end{array}$ & $\begin{array}{c}0.001 \\
(0.001)\end{array}$ \\
\hline \multicolumn{4}{|l|}{ Legislative behavior: } \\
\hline Distance from the median & $\begin{array}{c}0.004 \\
(0.005)\end{array}$ & $\begin{array}{l}-0.007 \\
(0.008)\end{array}$ & $\begin{array}{l}-0.012^{*} \\
(0.007)\end{array}$ \\
\hline Bill sponsorship & $\begin{array}{l}0.025^{\text {** }} \\
(0.012)\end{array}$ & $\begin{array}{l}0.038^{\star \star} \\
(0.018)\end{array}$ & $\begin{array}{c}0.016 \\
(0.031)\end{array}$ \\
\hline Outward cosponsorship & $\begin{array}{l}-0.016 \\
(0.012)\end{array}$ & $\begin{array}{l}-0.030 \\
(0.029)\end{array}$ & $\begin{array}{c}0.013 \\
(0.016)\end{array}$ \\
\hline Inward cosponsorship & $\begin{array}{c}-0.035^{\star} \\
(0.019)\end{array}$ & $\begin{array}{c}-0.055^{\star \star} \\
(0.028)\end{array}$ & $\begin{array}{l}-0.018 \\
(0.040)\end{array}$ \\
\hline \multicolumn{4}{|l|}{ Changes in legislative behavior: } \\
\hline Changes in distance from the med. & $\begin{array}{l}0.011^{\star} \\
(0.006)\end{array}$ & $\begin{array}{c}0.031^{\star \star \star} \\
(0.012)\end{array}$ & $\begin{array}{c}-0.013 \\
(0.010)\end{array}$ \\
\hline Changes in bill sponsorship & $\begin{array}{c}-0.033^{\star *} \\
(0.015)\end{array}$ & $\begin{array}{c}-0.046^{\star *} \\
(0.023)\end{array}$ & $\begin{array}{l}-0.006 \\
(0.024)\end{array}$ \\
\hline Changes in outward cosponsorship & $\begin{array}{l}-0.004 \\
(0.022)\end{array}$ & $\begin{array}{c}0.004 \\
(0.039)\end{array}$ & $\begin{array}{l}-0.005 \\
(0.032)\end{array}$ \\
\hline Changes in inward cosponsorship & $\begin{array}{l}0.041^{*} \\
(0.022)\end{array}$ & $\begin{array}{l}0.069^{\star *} \\
(0.035)\end{array}$ & $\begin{array}{c}-0.005 \\
(0.036)\end{array}$ \\
\hline Selection term & & $\begin{array}{c}0.922^{\star \star \star} \\
(0.370)\end{array}$ & $\begin{array}{c}0.296 \\
(0.401)\end{array}$ \\
\hline Congress dummies & Yes & Yes & Yes \\
\hline Pseudo $R^{2}$ & 0.332 & 0.358 & 0.275 \\
\hline
\end{tabular}

Table. 5: SELECTION MODEL BY GROUP II

Column (1) reports marginal effects at the mean, where the dependent variable is one for retirement. Columns (2) and (3) report marginal effects at the mean, where the dependent variable is one for lobbying. Standard errors are in the parentheses, and likelihood ratio tests are reported.

***Significant at 1 percent, ${ }^{* *}$ Significant at 5 percent, ${ }^{*}$ Significant at 10 percent. 


\begin{tabular}{cccc}
\hline \hline & Endowments effect & Coefficients effect & Unexplained part \\
\hline Overall (from Table 4) & -0.100 & $-0.202^{\star \star}$ & 0.140 \\
& $(0.075)$ & $(0.085)$ & $(0.101)$ \\
Legislator characteristics & -0.001 & -0.806 & 0.327 \\
& $(0.105)$ & $(0.505)$ & $(0.214)$ \\
Legislative behavior & -0.055 & $0.215^{\star}$ & -0.241 \\
& $(0.085)$ & $(0.175)$ & $(0.201)$ \\
Changes in legislative behavior & -0.015 & -0.007 & -0.008 \\
& $(0.050)$ & $(0.040)$ & $(0.062)$ \\
Overall (from Table 5) & -0.101 & $-0.212^{\star \star}$ & 0.138 \\
& $(0.089)$ & $(0.098)$ & $(0.113)$ \\
Legislator characteristics & -0.047 & 0.252 & 0.075 \\
& $(0.084)$ & $(0.604)$ & $(0.101)$ \\
Legislative behavior & -0.042 & 0.096 & 0.034 \\
& $(0.051)$ & $(0.307)$ & $(0.068)$ \\
Changes in legislative behavior & -0.022 & -0.047 & 0.019 \\
& $(0.037)$ & $(0.042)$ & $(0.056)$ \\
\hline
\end{tabular}

Table. 6: DECOMPOSITION OF PROBABILITY DIFFERENTIAL

Each effect is evaluated at the mean. The reference group is the retirement group, so that a minus sign indicates a lower probability of becoming a lobbyist for the voted-out group. Each panel decomposes probit index based on the results shown in Tables 4 and 5. Standard errors are in the parentheses.

***Significant at 1 percent, ** Significant at 5 percent, $*$ Significant at 10 percent. 